https://jurnal.uns.ac.id/jdc

\title{
Studi Tentang Kemampuan Penulisan Item Tes Guru Sekolah Dasar
}

\section{Sri Wuryanti, Muhardis}

Kementerian Pendidikan dan Kebudayaan

sriwuryanti03@gmail.com

\section{Sejarah Artikel}

diterima 28 September 2020 disetujui 20 November 2020 diterbitkan 1 Desember 2020

\begin{abstract}
The purpose of this research is to obtain information about the ability of elementary school teachers in preparing material tests in the semester. This research uses qualitative research, which describes empirical reality using a descriptive approach. This study also uses a literature study, with documents to find some field data that occurs in the form of questions on several subjects. Meanwhile, the data analysis used was (1) the subject matter expert's justification in interpreting some of the findings of the test item document, (2) theoretically and empirically, it was found that the test items did not meet the standard question rules. The assessment also using offline and online, it was found, among others, (1) biased test questions, because of the linguistic structure of the main sentence and explanatory sentences, wrongly choosing questions with answers, (2) not understanding the rules about the questions: such as homogeneity distractor questions, long and short answers, the use of standard Indonesian. Meanwhile, some of the test questions that were found to have problems were Indonesian, Natural Science, Character, Boy Scouts, Arts and culture. Of the 12 test items, 4 errors in the material concept and 9 errors in the rules of writing the questions
\end{abstract}

Keywords: test, understanding of concepts, rules of questions, subjects, assessment.

\begin{abstract}
Abstrak
Tujuan dari penelitain ini adalah untuk memperoleh informasi tentang kemampuan guru SD dalam menyusun item test dalam penilaian tengah semester. Penelitian ini menggunakan jenis penelitian kualitatif yaitu menggambarkan realitas empirik dengan menggunakan pendekatan deskriptif. Adapun, analisis data yang digunakan adalah dengan (1) justifikasi ahli mata pelajaran dalam menginterpretasi beberapa temuan dokumen item test, (2) secara teoritis dan empiris ditemukan item test tidak memenuhi standar kaidah penulisan soal. Asesmen juga mengunakan luring dan daring dengan begitu ditemukan antara lain, (1) item test yang bias, karena stuktur kebahasaan tentang kalimat utama dan kalimat penjelas, salah dalam memilih pertanyaan dengan jawaban, (2) kurang memahami kaidah penulisan soal: seperti homogenitas pengecoh soal, panjang pendek jawaban, penggunaan bahasa Indonesia yang baku. Sedangkan, beberapa item test yang ditemukan mengalami masalah adalah mata pelajaran Bahasa Indonesia, IPA, Budi Pekerti, pramuka, SBDP. Dari, 12 item test tersebut, 4 kesalahaan dalam konsep materi dan 9 kesalahaan dalam kaidah penulisan soal.

Kata kunci: Test, pemahaman konsep, Kaidah penulisan soal, mata pelajaran, asesmen.
\end{abstract}




\section{PENDAHULUAN}

Pandemi covid-19 ini mewajibkan orangtua mengajar anak-anak dirumah dengan Pembelajaran jarak jauh. Pembelajaran berlangsung dengan luring ataupun daring. Pembelajaran yang dilakukan dengan metode daring diantaranya menggunakan google dokumen. Sementara, untuk metode luring adalah mengirim materi menggunakan google document. Sementara, untuk metode luring adalah mengirim materi pembelajaran dengan video, PPT melalui whatsapp oleh wali murid. Demikian pula dengan asesmen atau penilaian yang dilakukan oleh guru. Pembelajaran dan asesmen yang dilakukan oleh guru dapat dilihat dan dipahami oleh orangtua atau walimurid dengan intens. Orangtua berusaha untuk mentransfer semua materi pelajaran yang diberikan oleh guru kepada anakanak dirumah setiap hari sejak PSBB atau pembatasan sosial berskala besar berlangsung. Namun, yang menjadi fokus perhatian dan permasalahan dari tulisan ini adalah isi dari item test dalam penilaian kelas. Masalah tersebut diantaranya: (1) beberapa item soal yang dibuat oleh guru yang kurang tepat dari materi pelajaran, dan (2) ada beberapa item test yang tidak sesuai dengan kaidah penulisan soal.

Item Test dalam asesmen pembelajaran kelas menurut Setiadi (2010) bahwa proses penilaian tidak dapat dipisahkan dari proses pembelajaran, mencerminkan dunia nyata, menggunakan beberapa kriteria atau metode, dan holistik mencakup aspek pembelajaran (kognitif, afektif, dan sensori-motorik). Oleh sebab itu dalam menyusun item test penilaian kelas seorang guru tidak menyimpang dari konsep materi pembelajaran, mengikuti kaidah penulisan soal, dan juga memperbanyak literasi membaca agar item test yang dihasilkan dapat digunakan untuk tujuan yang tepat. Adapun tujuan asesmen kelas adalah untuk, (1) penelusuran: agar pembelajaran sesuai rencana, (2) pengecekan: mengecek kelemahankelamahan yang dialami pesert didik, (3) pencarian: menganalisis dan merefleksi yang menyebabkan pembelajaran tidak efektif, dan (4) penyimpulan: menyimpulkan apakah siswa sudah dapat menguasai kompetensi sesuai kurikulum.

Negara yang unggul dalam kompetisi bukanlah negara yang sekadar mempunyai kekayaan sumber daya alam. Negara yang akan memenangi kompetisi adalah negara yang menguasai teknologi, negara yang mampu mendidik warganya untuk menjadi manusia pemikir dan menjadikan manusia unggul. Mutu sumber daya manusia (SDM) sangat berpengaruh terhadap kemajuan dan kemakmuran suatu bangsa. Bangsa dengan SDM yang baik dan bermutu diharapkan dapat bersaing dengan bangsa-bangsa lain di dunia di masa era globalisasi ini. Mutu sumber daya manusia yang baik hanya dapat dilakukan dengan usaha yang terencana dan sistematis melalui pendidikan yang bermutu. Pendidikan bermutu tidak semudah kita membalikkan telapak tangan. Pendidikan harus dirancang sebaik mungkin agar proses belajar mengajar dikelas berjalan optimal. Pembelajaran di kelas selayaknya meninggalkan cara belajar yang konvensional yang sekadar mengejar nilai dan mengabaikan kompetensi. Guru sebagai pendidik harus dibekali berbagai macam fasilitas terutama meningkatkan kompetensi pengetahuan guru, metode mengajar, serta penguasaan kurikulum, serta penguasaan penilaian. Rendahnya 
minat baca dan kebiasaan membaca peserta didik menjadikan kemampuan membaca menjadi rendah dan itulah yang sekarang terjadi pada masyarakat kita sekarang ini.

Kaum milenium harus cerdas memilah dan memilih informasi yang dibutuhkan. Pembelajaran abad ke-21 menuntut peserta didik harus memiliki kecakapan esensial yaitu dapat berpikir kritis, kreatif dan inovatif dan pemecahan masalah, serta berkolaborasi dan berkomunikasi efektif. Kecakapan esensial tersebut sangat diperlukan oleh peserta didik sebagai anggota masyarakat yang bermanfaat dalam kehidupan. Guru masih banyak menggunakan pola lama dalam mengajar dan melakukan penilaian, sehingga kemampuan peserta didik dalam menggunakan nalar untuk menyelesaikan masalah masih jauh dari harapan. Terkait dengan hal tersebut, diperlukan suatu penelitian untuk mengetahui kompetensi guru SD, sehingga diperoleh masukkan untuk perbaikan kualitas pendidikan.

Kaidah penulisan soal pilihan ganda menurut Nizam (2017) adalah (1) materi soal sesuai indikator, pilihan jawaban homogeny dan logis, serta memiliki jawaban yang benar. (2) konstruksi soal pokok soal dirumuskan dengan jelaas dan tegas, rumusan pokok soal yang diperlukan saja, pokok soal jangan memberi petunjuk kea rah jawaban benar, jangan mengandung pernyataan negative ganda, panjang rumusan pilihajawaban harus sama, jangan mengandung pilihan diatas salah atau semua pilihan jawaban benar, pilihan jawaban berdasarkan urutan terkecil atau terbesar, gambar atau tabel harus berfungsi, dan butir soal jangan bergantung pada jawaban soal sebelumnya. (3) Bahasa: menggunakan bahasa yang sesuai kaidah bahasa Indonesia, jangan menggunakan bahasa yang berlaku setempat, menggunakan bahasa yang komunikatif, dan setiap pilihan jawaban jngan mengulang frase yang merupan satu kesatuan pengertian. Dan, catatan penting tidan menyinggung SARA, tidak bermuatan politik, pornografi, kekerasan, menggunakan nama instansi, dan tidak promosi.

Sedangkan, kaidah penulisan soal uraian menurut tim Puspendik (2010) adalah (1) materi: soal harus sesuai indikator, batasan pertanyaan harus jelas, isi materi sesuai dengan petunjuk pengukuran, da nisi materi sesuai jenjang. (2) konstruksi: rumusan kalimat menggunakan kata tanyaatau perintah, buat petunjuk soal yang jelas, buat pedoman penskoran, dan hal-hal lain seperti tabel atau gamber harus disajikan dengan jelas dan bermakna. (3) Bahasa: menggunakan bahasa yang sederhana dan komunikatif, tidak menyinggung peserta didik, rumusan soal tidak menggunakan kata/kalimat yang menimbulkan penafsiran ganda, menggunakan bahasa yang baik dan benar, rumusan soal mempertimbangkan bahasa dan budaya, serta tidak menngunakan bahasa setempat. Catatannya adalh segera membuat pedoman penskoran setelah ditulis kalimat pertanyaan.

Menurut Abdurrahman (2003), membaca pada hakekatnya merupakan aktivitas kompleks yang melibatkan banyak hal, tidak hanya sekedar melafalkan tulisan, tetapi juga mencakup penggunaan pengertian, aktivitas visual, pengamatan, dan berfikir. Sejalan dengan kedua ahli tersebut Zuchdi dan Budiasih (2001) mengatakan bahwa dengan membaca seseorang dapat memperoleh informasi, ilmu pengetahuan dan pegalamanpengalaman baru. Untuk mewujudkan hal tersebut pendidik harus dapat merancang dan menyampaikan materi pembelajaran dengan baik terutama kemampuan berbahasa, berfikir, dan penguasaan materi pelajaran. Namun demikian tidak semua pendidik mempunyai kemampuan tersebut. 
Menurut hasil penelitian yang dilakukan Susilaningsih (2013) hanya 37\% dari pendidik yang dapat menyampaikan materi pelajaran dengan jelas. Sedangkan menurut hasil penelitian yang dilakukan Guritaningsih dkk (2000) rendahnya mutu pendidikan disebabkan oleh rendahnya prestasi belajar, kesulitan siswa dalam memahami dan menguasai materi pelajaran, ketidakmampuan berfikir kritis dan menerapkan pengetahuan yang diperoleh di sekolah pada situasi yang berbeda. Hasil penelitian tersebut harus menjadi perhatian semua pihak terutama Pemerintah untuk memperbaiki kualitas mengajar pendidik. Dalam pembelajaran di kelas, pendidik harus mempersiapkan diri dengan baik dalam menyampaikan materi pelajaran kepada anak didik. Kesiapan pendidik meliputi penguasaan materi pelajaran, program, strategi, dan metode pembelajaran. Strategi pembelajaran mempunyai peranan khusus dalam proses belajar mengajar di kelas terkait dengan seberapa besar peserta didik dapat menyerap materi pelajaran khususnya materi yang berkaitan dengan proses berfikir kritis dan kreatif atau bernalar. Menurut Kemdiknas (2010) pada dasarnya ada tiga level kognitif untuk mendapatkan gambaran secara spesifik tentang tingkat kemampuan peserta didik, yaitu: pengetahuan dan pemahaman, aplikasi dan penalaran. Peserta didik pada level pengetahuan dan pemahaman memiliki kemampuan standar minimum dalam menguasai pelajaran; peserta didik pada level aplikasi memiliki kemampuan memperlihatkan pengetahuan dan pemahaman terhadap materi pelajaran dan dapat mengaplikasikan gagasangagasan dan konsep-konsep dalam konteks tertentu; sedangkan peserta didik pada level penalaran memiliki kemampuan menganalisis, mensintesis, mengevaluasi, menginterpretasi, memecahkan masalah, dan mendemonstrasikan pemikiran- pemikiran yang original. Untuk mengetahui seberapa besar peserta didik menyerap materi pelajaran dengan baik dapat dilakukan dengan evaluasi atau penilaian. Salah satu alat penilaian yang dapat digunakan untuk mengukur kemampuan peserta didik adalah tes tertulis. Menurut Cronbach (1960), tes sebagai prosedur yang sistematis untuk memperoleh sampel perilaku peserta didik. Dari pendapat ahli tersebut dapat disimpulkan bahwa tes merupakan alat ukur standar yang digunakan untuk meperoleh informasi tentang kemampuan yang dimiliki oleh peserta tes. Tes sebagai alat ukur harus memenuhi prasyarat sebagai alat ukur yang baik yaitu tes tersebut harus valid dan reliabel. Menurut Brennan (2006), validitas tes atau kesahihan suatu tes adalah kemampuan suatu tes untuk mengukur karakteristik atau dimensi sesuai dengan apa yang ingin diukur, sedangkan reliabilitas atau kehandalan suatu tes mengacu pada derajat suatu tes yang mampu mengukur berbagai atribut secara konsisten. Konstruksi tes yang baik harus memenuhi kedua syarat tersebut, sehingga tes itu mampu memberikan gambaran yang sebenarnya terhadap kondisi testee (orang) yang diuji, sedangkan menurut Anastasi dan Urbana (1988), reliabilitas tes merupakan kestabilan skor yang diperoleh orang yang sama ketika mereka diuji ulang dengan tes yang sama pada saat yang berbeda atau dengan perangkat soal-soal ekuivalen yang berbeda, atau pada kondisi pengukuran yang berbeda. Tes sebagai alat ukur memegang peranan penting dalam proses belajar mengajar di kelas. Hasil tes dapat digunakan untuk mengetahui prestasi belajar siswa dan dapat digunakan untuk memperbaiki mutu pendidikan. Hasil tes tersebut dapat berupa nilai atau daya serap (dalam persen) materi pelajaran. Menurut Depdikbud (2012), daya serap adalah seberapa besar secara 
persentase peserta didik dapat menjawab pertanyaan dalam tes, daya serap atau penguasaan materi ini diperoleh dari hasil perhitungan jawaban peserta didik dari setiap kemampuan yang diujikan di setiap jenjang. Untuk tes prestasi belajar ranah yang diukur berkaitan dengan level kognitif. Untuk menulis butir soal yang menuntut penalaran tinggi dibutuhkan penguasaan materi pelajaran yang baik, kreatif, serta keahlian dalam menulis soal khususnya dalam kontruksi soal.

Permasalahannya adalah beberapa guru tidak semuanya mampu menyusun tes yang baik untuk digunakan sebagi refleksi hasil belajar siswa. Seperti penelitian yang dilakukan oleh Susiati (2019) menyebutkan bahwa SDN Janti Jogoroto menyatakan bahwa $82 \%$ tidak disertai kisi-kisi dan beberapa kis-kisi yang berhasil. Berdasarkan analisa bahwa jika soal disusun dari kisi-kisi yang salah akan menghasilkan soal yang salah. Soal yang salah sudah pasti tidak dapat digunakan untuk mengukur capaian kompetensi dasar yang diharapkan. Beberapa masalah pokok yang menyebabkan minimnya kisi-kisi yang dimiliki guru-guru adalah karena ketidakpahaman. Sedangkan, penelitian dari Realita (2019) menyebutkan bahwa Kesulitan guru dalam menyusun instrument asesmen yaitu menentukan kata kerja operasional, cara menyusun bahasa yang baik sesuai dengan EYD
(Ejaan yang Disempurnakan) dan redaksi bahasa yang komunikatif, menyusun aspek-aspek yang dinilai dalam instrumen afektif dan psikomotor, menyesuaikan antara indikator dan instrumen soal/aspek-aspek penilaian, dan teknik menentukan opsi (pilihan) jawaban yang logis dan homogen pada soal berbentuk pilihan ganda dan menjodohkan. Berdasarkan penelitian tim peneliti Balitbangda (2005) Provinsi Sumatera Utara tentang kemampuan guru dalam membuat alat evaluasi untuk digunakan dalam KBM diketahui beberapa data penelitian persoalan guru dalam membuat item test adalah soalsoal yang salah karena tidak adanya kisi-kisi, kesulitan dalam menentukan kata kerja operasional, penggunaan bahasa yang benar, dan hanya 3,50\% membuat alat evaluasi dengan baik, serta hanya $15,3 \%$ mampu menganalisa evaluasi hasil belajar siswa dalam proses belajar mengajar.

Permasalahan yang dikemukakan dalam penelitian ini adalah bagaimana kemampuan guru kelas dalam menyususun asesmen kelas dilihat dari kecocokan asesmen dengan materi pelajaran dan kaidah penulisan soal. Tujuan penelitian ini adalah untuk mengetahui item test yang dibuat oleh guru kelas dalam menyusun asesmen kelas dengan memperhatikan standar kecocokan asesmen dengan materi pelajaran dan penulisan soal.

\section{METODE}

Penelitian ini menggunakan jenis medote penelitian deskriftif kualitatif yaitu menggambarkan fenomena penilaian kelas dengan menginterpretasi item test yang disusun oleh guru yang terjadi saat pembelajaran jarak jauh pandemi covid-19 tahun pelajaran 20202021 pada salah satu Sekolah dasar kelas IV. Adapun, sumber datanya adalah berupa data sekunder, yaitu teksteks penilaian kelas berupa lembar penilaian guru yang diberikan pada siswa pada saat ulangan harian, dan tugas-tugas harian lainnya. Alat pengumpulan data yang digunakan berupa dokumen kumpulan naskah item test yang terdapat dalam penyimpan data android dalam aplikasi whatsapp grup wali murid dan juga link google document. Teknik analisa yang dipergunakan adalah analisis content, dengan menelaah dan mereview 
beberapa item test menggunakan disusun oleh Pusat Asesmen dan standar kaidah penulisan soal yang Pembelajaran, Balitbang, Kemdikbud.

\section{PEMBAHASAN}

Dokumentasi yang terkumpul dalam penelitian ini adalah, ada 12 item test dari mata pelajaran Bahasa Indonesia, IPA, Pramuka, Budi Pekerti, dan SBDP. Adapun item test yang kami susun dengan butir soal antara 1 sampai dengan 12 sebagai berikut:

1) Item test mata pelajaran Bahasa Indonesia

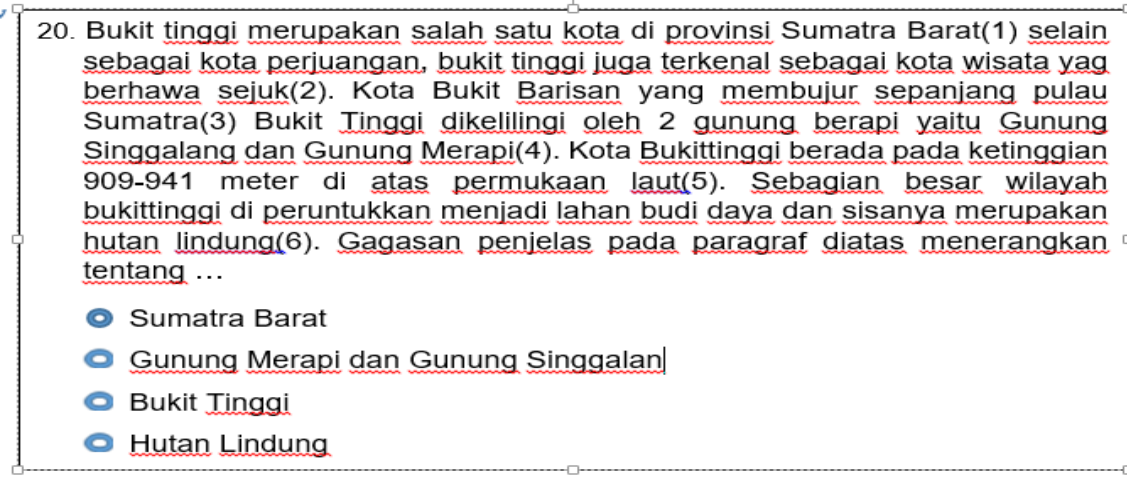

Pada item test tersebut berbentuk pilihan ganda maka bias karena menanyakan tentang gagasan penjelas, sedangkan gagasan penjelas diketahui seharusnya tidak hanya terdiri dari satu pilihan jawaban, karena gagasan penjelas menerangkan hal-hal yang berkaitan gagasan utama.

2) Item tes mata pelajaran Bahasa Indonesia

16. Hari ini tanggal 17 Agustus(1) sekolah Dini mengadakan lomba karnaval
pakaian daerah(2) Dita dan teman-temannya mengikuti lomba(3).
Gagasan pokok pada paragraf tersebut ditunjukkan oleh no ...
O 2
○ 3
○ 1
○ 1,23

Item test tersebut tidak mengikuti kaidah soal tentang tentang homogenitas pertanyaan dimana gagasan utama dan penjelasnya kurang spesifik, dan kedua pilihan jawaban terakhir menyiratkan bahwa jawaban 123 benar, hal ini tidak dibenarkan.

3). Item test mata pelajaran Bahasa Indonesia

14. Kerukunan dan toleransi umat beragama di Alor terwujud karena masyarakatnya mempunyai asal usul yang sama(1). Jadi(oleh karena itu) tidak ada alasan bagi siapapun untuk berprasangka buruk terhadap penganut agama lain(2). Di alor sudah lazim dalam 1 keluarga bisa berbeda-beda keyakinan(3). Gagasan pokok pada paragraf pada diatas ditunjukkan oleh no...
(-) 1
(1) 2
(?) 3
( 1 dan 2
(-)psi 5 
Item test tersebut diatas tidak mengikuti kaidah soal tentang homogenitas pengecoh soal antara gagasan pokok dengan gagasan penjelas. Terlihat, antara gagasan pokok dan penjelas sangat bertentangan.

4) Item test mata pelajaran IPA

8. Bunyi tidak dapat di dengar di ruang angkasa karena ... *

- Di ruang angkasa tidak ada udara yang dapat merambatkan atau menghantarkan

( ) Di ruang angkasa sangat dingin

Di ruang angkasa gelap gulita

Di Ruang angkasa jauh dari bumi

Item test tersebut tidak mengikuti kaidah soal tentang panjang pendeknya pilihan jawaban dan juga mengulang-ulang kata "diruang angkasa" yang sebenarnya sudah ada dalam pertanyaan jawaban.

5) Item test mata pelajaran IPA

19. Bagian telinga tengah terdiri dari......

Saluran eustachius

Tulang martil, tulang sanggurdi dan tulang landasan

( Rumah siput

- Tingkap jorong

Item test tersebut tidak sesuai dengan konsep materi IPA yang spesifik, karena bagian telinga tengah terdiri dari gendang telinga, ossicles, dan tuba eustachius. Sedangkan pada jawaban diatas merupakan bagian dari assicles.

6) Item test mata pelajaran Pramuka

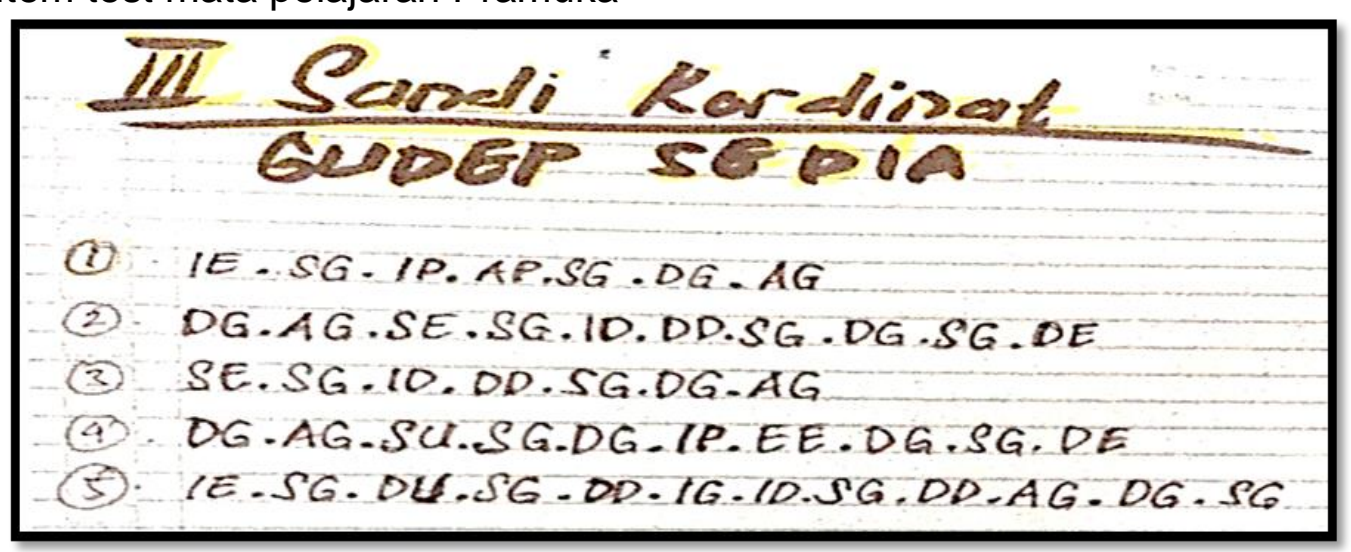

Item test tersebut kelimanya diminta untuk menerjemahkan kedalam alfhabet bahasa Indonesia, dan setiap jawaban diplesetkan dalam bahasa yang tidak 
bermakna. Oleh sebab itu tidak mengkuti kaidah bahasa yang benar karena tidak menggunakan bahasa Indonesia yang baik dan benar.

7) Item test mata pelajaran Budi Pekerti

11. Ani mempunyai teman yang kakinya pincang. Ani tidak pernah mengejek temannya tersebut.ia malag sering belajar bersama.sikap ni terhadap temannya adalah*

- Menghargai dan menghormati

- Setia kawan

- Rela berkorban

- Menjaga dan melindungi

Item test tersebut kurang baik karena akan menyakiti hati teman-teman siswa inklusi yang mungkin membaca soal ini. Sebaiknya dihindari pilihan kata cacad dan bisa diperhalus dengan teman berkebutuhan khusus.

8) Item Test pelajaran Budi Pekerti

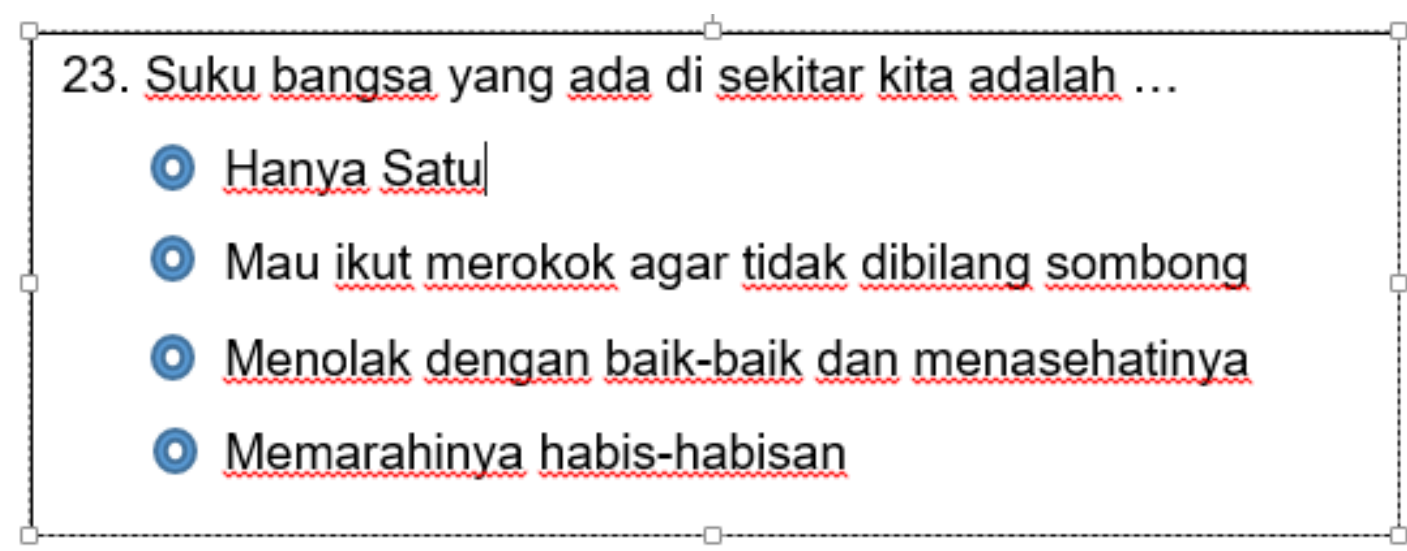

Item test tersebut kurang baik karena tidak ada jawaban yang benar dan tidak homogen antara soal dengan pilihan jawaban. Serta, pilihan jawaban diksi merokok sebaiknya juga dihindari karena tidak sesuai dengan usia siswa kelas 4 SD

9) Item test mata pelajaran Budi Pekerti

13. Mencontek bersama teman adalah ...

- Tidak baik Karena bekerja sama dalam keburukan

- Baik karena setia kawan

- Baik karena saling membantu

- Boleh saja asal tidak ketahuan guru

Item test tersebut tidak memperhatikan panjang pendek jawaban, dan beberapa kata tidak memperhatikan pemakain bahasa yang baik. 
10) Item test mata pelajaran Budi Pekerti

19. Jika kalian mencegah teman yang akan memakai narkoba, maka tindakan kalian terhadap teman itu berarti ...*

○ Tidak setia kawan

- Menjaga dan menghormati teman

- Saling menghormati

○ Melanggar norm agama

Item soal tersebut kurang bagus, karena pemilihan diksi narkoba sebaiknya dihindari dan pilihan jawaban sebaiknya yang homogen.

11) Item test mata pelajaran Budi Pekerti

22. Jika kalian ditawari merokok oleh teman, tindakan kalian adalah ..

- Mau merokok agar setia kawan

- Mau ikut merokok agar tidak dibilang sombong

- Menolak dengan baik-baik dan menasihatinya

- Memarahiny habis-habisan

Item soal tersebut kurang bagus karena memilih diksi "merokok berulangulang, memarahi, dan sombong" sebaiknya dihindari untuk pilihan contoh soal dan pilihan jawaban tersebut. Karena, dapat diganti dengan diksi yang lebih positif dan lebih membangun karakter anak.

12) Item test mata pelajaran SBDP

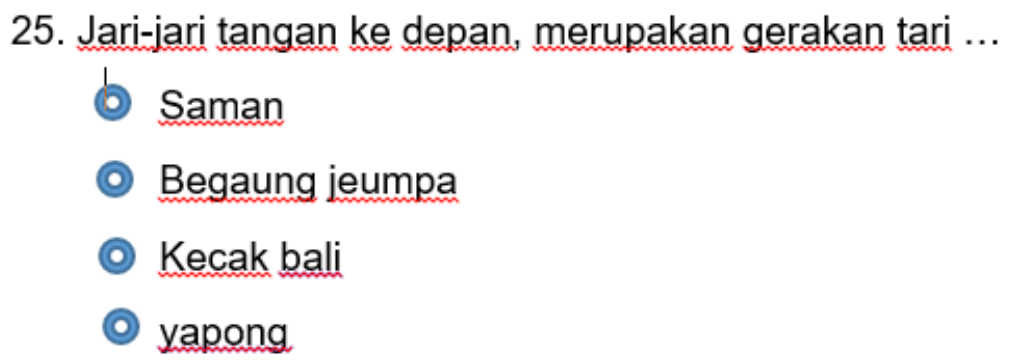

25. Jari-jari tangan ke depan, merupakan gerakan tari ...

Saman

○ Begaung jeumpa

- Kecak bali

yapong

Item test pada soal ini kurang spesifik, karena semua tarian ada gerakan seperti yang dideskripsikan dalam pertanyaan.

Dari item test diatas dapat ditarik kesimpulan bahwa ada beberapa soal yang kurang sesuai konsep pelajaran dan kaidah penulisan soal diantaranya:

Tabel 1.

Rekap Hasil Telaah Dan Review Soal

\begin{tabular}{|l|l|l|l|}
\hline $\begin{array}{c}\text { No } \\
\text { Soal }\end{array}$ & \multicolumn{1}{|c|}{$\begin{array}{c}\text { Mata } \\
\text { pelajaran }\end{array}$} & \multicolumn{1}{|c|}{ Konsep } & \multicolumn{1}{c|}{ Kaidah penulisan soal } \\
\hline 1$)$ & $\begin{array}{l}\text { Bahasa } \\
\text { Indonesia }\end{array}$ & $\begin{array}{l}\text { Tidak dapat menafsirkan } \\
\text { gagasan utama dan gagasan } \\
\text { penjelas }\end{array}$ & - \\
\hline 2$)$ & $\begin{array}{l}\text { Bahasa } \\
\text { indonesia }\end{array}$ & $\begin{array}{l}\text { Tidak homogen antara } \\
\text { gagasan utama dan penjelas }\end{array}$ & $\begin{array}{l}\text { Jawaban 12 3 benar karena tidak boleh } \\
\text { ada keterkaitan antara pilihan jawaban. }\end{array}$ \\
\hline 3$)$ & $\begin{array}{l}\text { Bahasa } \\
\text { Indonesia }\end{array}$ & - & $\begin{array}{l}\text { Panjang pendek pilihan jawaban dan } \\
\text { mengulang-ulang kata. }\end{array}$ \\
\hline
\end{tabular}




\begin{tabular}{|l|l|l|l|}
\hline 4$)$ & IPA & - & $\begin{array}{l}\text { Mengulang-ulang kata dalam pilihan } \\
\text { jawaban }\end{array}$ \\
\hline 5$)$ & IPA & $\begin{array}{l}\text { Tidak dapat membedakan } \\
\text { bagian telinga tengah dengan } \\
\text { sub bagiannya }\end{array}$ & - \\
\hline 6$)$ & Pramuka & - & $\begin{array}{l}\text { Tidak meggunakan bahasa Indonesia } \\
\text { yang baik dan benar }\end{array}$ \\
\hline 7$)$ & Budi Pekerti & - & Penggunaan diksi cacad \\
\hline 8$)$ & Budi Pekerti & - & $\begin{array}{l}\text { Pilihan jawaban tidak homogen dan } \\
\text { pilihan diksi rokok }\end{array}$ \\
\hline 9$)$ & Budi Pekerti & - & $\begin{array}{l}\text { Panjang pendek pilihan jawaban dan } \\
\text { penulisan kurang baik }\end{array}$ \\
\hline 10) & Budi Pekerti & & Pemilihan diksi narkoba \\
\hline 11$)$ & Budi Pekerti & & Pemilihan diksi kurang baik \\
\hline 12) & SBDP & Pertanyaan tidak spesifik & - \\
\hline & Jumlah & 4 & 9 \\
\hline
\end{tabular}

Berdasarkan justifikasi ahli materi mata pelajaran Bahasa Indonesia dan science, dengan menggunakan standar panduan penulisan soal asesmen test dari pusat asemen dan pembelajaran kemdikbud beberapa lembaran dokumen test ulangan harian yang terdiri dari 12 item telah diinterpretasi secara detail dan dapat ditemukan informasi sebagai berikut:

Pertama adalah kesalahan dalam konsep materi pelajaran yaitu; (1) pada mata pelajaran Bahasa Indonesia ada dua Item test tentang kesalahan pemahaman dan penafsiran guru dalam menyebutkan materi gagasan utama dan gagasan penjelas. Sejalan dengan temuan yang dilakukan oleh Fahmi (2020) bahwa Sebanyak 14\% guru SD pada sampel penelitian yang dilakukan dengan kategori baik mendapat nilai di atas 80, hal ini menunjukkan bahwa sebagian besar guru masih kurang menguasai materi pelajaran Bahasa Indonesia. Ke-(2) materi pelajaran science tentang kesalahan dalam menyebutkan bagian dan sub bagian telinga tengah. Sesuai dengan penelitian Lestari (2019) bahwa beberapa siswa mengalami miskonsepsi pada pelajaran IPA yang disebabkan kesalahan penyampaian guru dalam materi Biologi di sekolah Dasar. Untuk yang ke-(3) adalah materi pelajaran SBDP ada item test kesalahan karena pertanyaan terlalu umum tentang gerakan sebuah tarian. Penelitian oleh Zulkifli (2005) bahwa materi praktik kesulitan bisa munculnya dari guru, terutama guru TK dan SD yang tidak memiliki kompetensi seni rupa sehingga perlu ditawarkan pendekatan yang bisa dilatihkan dan dikembangkan guru.

Kedua adalah penggunaan kaidah penulisan item test yang masih banyak ditemukan kesalahan antara lain; (1) pada pelajaran Bahasa Indonesia yaitu mengaitkan antar jawaban pada pilihan ganda, panjang dan pendek jawaban tidak sama, dan mengulang-ulang kata yang sama. Ke-(2) Pada pelajaran Pramuka adalah jawaban dari pertanyaan tersebut tidak menggunakan bahasa Indonesia yang tepat pada jawabannya atau tidak mengikuti Indonesia yang baik dan benar. (3) Untuk materi science ada dua item test adalah pengulangan kata. Sesuai dengan penelitian Nengapti (2014) bahwa berdasarkan hasil wawancara yang dilakukan, ketidaktepatan penggunaan bahasa dalam soal Ujian Akhir Semester di SD disebabkan oleh faktor kompetensi yakni sebagai berikut; pemahaman atau pengetahuan tentang kaidah bahasa Indonesia yang baik dan benar yang kurang dikuasai oleh pembuat soal, pengaruh bahasa percakapan, dan Kekeliruan disebabkan oleh faktor performansi yakni kekeliruan 
yang dilakukan pembuat soal karena pengaruh situasi dan kondisi lingkungan sekitar. Ke-(4) materi Budi pekerti ada lima item test dan jenis kesalahannya antara lain penggunaan diksi Sara, pemilihan diksi barang terlarang dan yang tidak sesuai dengan anak usia SD, serta pilihan jawaban pada pilihan ganda tidak homogen dan kurang memperhatikan panjang pendek jawaban. Mufida (2015) pokok soal yang tidak dirumuskan secara jelas dan tegas, terdapat penulisan pokok soal dan pilihan jawaban yang bukan merupakan pernyataan yang diperlukan saja, terdapat pilihan jawaban yang tidak homogen, panjang alternatif atau pilihan jawaban tidak sama, pokok soal yang memberi petunjuk atau mengarah kepada pilihan jawaban yang benar, pilihan jawaban dalam bentuk angka/ waktu yang tidak diurutkan, terdapat jawaban yang tidak logis dan pengecohnya tidak berfungsi, terdapat rumusan kalimat yang tidak komunikatif, terdapat kalimat yang tidak menggunakan bahasa yang baik dan benar, dan terdapat rumusan kalimat yang menimbulkan penafsiran ganda.

Berdasarkan pedoman penulisan soal secara teoritis, interpretasi secara empiris oleh ahli materi pelajaran Bahasa dan Science, serta beberapa hasil penelitian sebelumnya bahwa item test yang disusun oleh guru pada ulangan harian di masa pandemi COVID-19 pada SD kelas empat yang menjadi subyek penelitian, ditemukan dua kesalahan yang sangat signifikan yaitu pemahaman konsep materi pelajaran dan penggunaan kaidah penulisan penulisan soal secara standar. Dengan demikian item test tersebut bias dan tidak dapat berfungsi sebagai alat ukur prestasi atau alat ukur hasil belajar siswa dikelas. Sejalan dengan penelitian Nuriyah (2014) yang menyatakan bahwa Sebuah tes dikatakan memiliki validitas isi atau tidak bias apabila isi tes disusun oleh butir-butir tes yang merepresentasikan kompetensi atau kemampuan siswa dan disusun sesuai kaidah penulisan soal yang benar.

\section{SIMPULAN}

Berdasarkan hasil penelitian sebelumnya dan beberapa temuan diantaranya rendahnya daya serap peserta didik dalam pemahaman konsep materi pelajaran disebabkan kesalahan konsep materi ajar dalam proses KBM, oleh Kemdikbud. Temuan lain adalah beberapa guru tidak semuanya mampu menyusun tes yang baik untuk digunakan sebagai refleksi hasil belajar siswa, seperti penelitian yang dilakukan oleh Susiati. Sedangkan, penelitian dari Balitbang Provinsi Sumut bahwa guru kesulitan dalam menyusun soal karena tidak menggunakan kisi-kisi, sulit menentukan kata operasional, dan penggunaan bahasa yang baik dan benar. Terakhir adalah penelitian dari Realita menyebutkan bahwa Kesulitan guru dalam menyusun instrumen asesmen yaitu menentukan kata kerja operasional, cara menyusun bahasa yang baik dan redaksi bahasa yang komunikatif, menyusun aspek-aspek yang dinilai dalam instrumen afektif dan psikomotor, menyesuaikan antara indikator dan instrumen soal/aspekaspek penilaian, dan teknik menentukan opsi yang homogen dalam menentukan jawaban.

Hasil penelitian dan pembahasan dari penelitian ini sesuai dengan beberapa penelitian dan temuan yang telah dilakukan sebelumnya. Untuk, penelitian ini dapat disimpulkan ada dua kesalahan guru dalam menyusun item test yaitu kesalahan dalam konsep materi pelajaran dan kedua adalah kesalahan dalam kaidah penulisan soal. 
1. Kesalahan konsep materi pelajaran, dalam penelitian ini ditemukan pada materi pelajaran Bahasa Indonesia, dimana guru kurang memahami gagasan utama dan gagasan penjelas. Serta kesalahan konsep di materi pelajaran IPA, dimana guru kurang memahami bagian telinga tengah dan sub bagiannya. Dan pelajaran SBDP dengan kurang spesifiknya menyebutkan tentang gerak tarian.

2. Kesalahan dalam kaidah penulisan soal diantaranya mengaitkan antara soal satu dengan soal sebelumnya, panjang-pendek jawaban tidak sama, pilihan jawaban tidak homogen, pemilihan diksi yang mengandung Sara, serta penggunaan bahasa Indonesia yang kurang tepat.

Peyusunan soal yang tidak mengikuti kaidah akan merugikan siswa dan tidak dapat digunakan untuk mengukur hasil belajar secara maksimal. Melihat kebermanfaatan penilaian kelas saat ini tujuannya sangat luas, untuk menentukan kelulusan siswa dan juga untuk melanjutkan siswa pada jenjang berikutnya Apalagi, dan juga untuk tujuan refleksi pembelajaran bagi siswa untuk mengobservasi kekurangan atau kelebihan siswa dalam menguasai kompetensi pembelajaran ataupun refleksi penyampaian pembelajaran guru. Oleh sebab itu masih perlu pelatihan yang lebih baik agar bapak dan ibu guru memiliki kompetensi dalam menyusun item test pengukuran yang baik dan bermakna. Maka, perlu ada pelatihan intensif penyusunan item test yang baku dan standar agar selaras antara proses pembelajaran dan asesmen yang dilaksanakan di dalam kelas.

\section{DAFTAR ISI}

Anastasi, Anne, and Urbina, Susana.(1988). Psychological Testing $6^{\text {th }}$. New York: Macmillan Publishing Company.

Ayu Titi Nengapti. (2014). Ketidaktepatan Penggunaan Bahasa Indonesia Pada Soal Ujian Akhir Semester I Bahasa Indonesia Kelas III SDN Jember Lor 05. Universitas Jember: 1 (1):1-5.

Badrun Kartowagiran dan Amat Jaidun. (2016). Model Asesmen Autentik untuk Menilai Hasil Belajar Siswa Sekolah Menengah Pertama (SMP): Implementasi Asesmen Autentik di SMP. Jurnal Penelitian dan Evaluasi Pendidikan. 3(2):1117

Brenan, Robert L. (2006). Educational Measurement. Washington:

American Council on Education Praeger. Charles D. Hopkins dan Richard L. Antes. (1979). Classroom Testing
Construction. Illionos: F. E. Peacock.

Crosker, Linda, James Algina. (1986). Introduction To Classical \& Modern Test Theory. Holt, Rinehart dan Winston. Inc. New York.

Departemen Pendidikan dan Kebudayaan. (2012). Buku Panduan Pemanfaatan Hasil UN, Jakarta: Pusat Pengujian.

Fahmi. (2020). Kemampuan Guru Sd Kelas IV Dalam Menyelesaikan Soal Bahasa Indonesia. Prosiding Kolita Atmajaya. 1(1)1-18.

Faizah, U.D., Sufyadi, S., dkk. (2016). Panduan Gerakan Literasi Sekolah di Sekolah Dasar. Jakarta: Direktorat Pembinaan Sekolah Menengah Pertama Dirjendikmen kemdikbud.

Gibson, R. Ed. (1998). "Rethinking the Future, Memikirkan Kembali Bisnis, Prinsip, Persaingan, Kontrol dan Kompleksitas, Kepemimpinan, 
Pasar, dan Dunia”. Jakarta: Gramedia Pustaka Utama.

Gronlund, N.E., Linn, D. R.L. (1990). Measurement and assessment in teaching. New York: Macmillan Publishing Company.

Hari Setiadi, (.2013). Prinsip-Prinsip dan Strategi Penilaian Dikelas. Jakarta Puspendik Balitbang Kemdikbud.

Harjasujana, A.S. (1988). "Nusantara yang Literat: Secercah Sumbang Saran terhadap Upaya Peningkatan Mutu Pendidikan di Indonesia". Bandung: IKIP Bandung.

Heryati, Y., dkk. (2010). Model Inovatif Pembelajaran Bahasa Indonesia. Jakarta: Multi Kreasi Satu delapan.

Kementerian Pendidikan dan Kebudayaan. (2018). Kurikulum 2013 Edisi Revisi 2018 Kelas 3, 6, 9, dan 12. Jakarta: Puskurbuk.

Kementerian Pendidikan dan Kebudayaan. (2016). Peringkat dan Capaian PISA Indonesia Mengalami Peningkatan. Jakarta.

Kementerian Pendidikan dan Kebudayaan. (2012). Buku Panduan Pemanfaatan Pamer UN2012, Jakarta: Pusat Penilan Pendidikan. Jakarta.

Kementerian Pendidikan Nasional. (2010). Tes Tertulis. Jakarta: Puspendik.

Lee J. Cronbach. (1960). Essentialof Psychological Testing, $3^{\text {th }}$ ed, New York: Harper \& Row.

Leonardo Sijabat,. (2014). Meningkatkan Kompetensi Guru Menyusun Instrumen Tes Melalui Model Pelatihan Ssott Di Sma Dan Smk Kabupaten Dairi. Jurnal Pendidikan Dan Kepengawasan. 3(1)1-24.

Nizam,. (2017). Panduan Penulisan Soal 2017. Jakarta: Puspendik Balitbang Kemdikbud.

Nunung Nuriyah. (2014). Evaluasi Pembelajaran. Jurnal Edueksos. 3(1)1-6.
Maria Ayu Dwi Lestari. (2019). Miskonsepsi IPA Biologi pada guru kelas $V S D$. Skripsi Universitas Sanata Dharma: 86.

Mufida Nofiana. (2015). Kualitas Penulisan Butir Soal Ujian Nasional Biologi Tahun 2014/2015 Ditinjau Dari Aspek Teoritik. Jurnal Saintifika;17(1)1-13.

Nunung Nuriyah. (2014). Evaluasi Pembelajaran Sebuah Kajian Teori. Edueksos; 3(1) 1-6.

PIRLS (2011). International Report. Performance at the PIRLS 2011. International Benchmarks TIMMS \& PIRLS Report International Study Center (IEA): Lynch School of Education. Boston College.

Pusmenjar. (2020). Desain Pengembangan Soal AkademikAKM. Jakarta.

Rahim, F. (2008). Pengajaran Membaca di Sekolah Dasar. Jakarta: Bumi Aksara.

Realita,. (2019). Kompetensi Guru Min Sabang Dalam Melaksanakan Evaluasi Pembelajaran; Telaah Atas Konstruksi Instrumen Penilaian Berbasis Kurikulum 2013. Jurnal IImiah Didaktika. 13(2) 2-19.

Santoso, Guritaningsih A. dkk.. (2000). Studi Perkembangan Kognitif Siswa SD. Jakarta: LIPI.

Setiadi, Hari. (2016). Pelaksanaan Penilaian pada Kurikulum 2013. Jurnal Penelitian dan Evaluasi Pendidikan. 20(2)11-17

Siswandari, Susilaningsih. (2013). Dampak Sertifikasi Guru Terhadap Peningkatan Kualitas Pembelajaran Peserta Didik. Jurnal Pendidikan dan Kebudayaan. 19(4) 487-498.

Suryabrata, Sumadi.

(1987). Pengembangan Tes Hasil Belajar. Jakarta: Rajawali.

Susiati, (2019). Meningkatkan Kemampuan Guru Dalam Menyusun Kisi-Kisi Soal Dengan Metode Pendampingan Pola "Ocf" . 
Jurnal Dinamika Manajemen Pendidikan. 4(1) 17-24.

Suyono. (2011). Pembelajaran Efektif dan Produktif Berbasis Literasi: Analisis Konteks, Prinsip, dan Wujud Alternatif Strategi Implementasinya di Sekolah. Malang: Penerbit Cakrawala Indonesia.

Widodo, Slamet, dkk. (2015), Membangun Kelas Literat Berbasis Pendidikan Lingkungan Hidup untuk Melatih Kemampuan Literat Siswa di Sekolah Dasar, dalam Prosiding Seminar Nasional Pendidikan : Tema "Peningkatan Kualitas Peserta didik Melalui Implementasi Pembelajaran Abad 21". Sidoarjo: FKIP Universitas Muhammadiyah Sidoarjo.

Zuchdi, D. dan Budiasih. (2001). Pendidikan Bahasa dan Sastra Indonesia di Kelas Rendah. Yogyakarta: PAS.

Zulkifli. (2005). Strategi Pembelajaran Seni Budaya Di Sekolah (Seni Rupa Dalam Materi Seni Budaya). Unimed: 4. 